\title{
Bush accused of power abuse over science
}

\section{Erika Check, Washington}

A prominent Congressman has accused the Bush administration of interfering with US science to such an extent that it is threatening public trust in both science and government.

Henry Waxman (Democrat, California) says that the administration has blocked the dissemination of scientific information, interfered with research results or sought undue influence in the composition of advisory panels, in its handling of a range of issues including AIDS and climate change.

On 7 August, Waxman's staff released a 33-page report, Politics and Science in the Bush Administration, detailing claims that President George Bush and his officials were improperly involving themselves in a variety of aspects of the scientific process.

The report covers allegations of interference at agencies including the National Institutes of Health (NIH), the Centers for Disease Control and Prevention, the Food and Drug Administration (FDA) and the Environmental Protection Agency. The report alleges that most of this has catered to a conservative or pro-business agenda. For instance, it recounts an attempt by the Department of Health and Human Services to appoint a doctor who opposed abortion to a key FDA committee on reproductive health.

"This report shows there is a pattern here that cannot be ignored,"Waxman says. "What we're talking about here is unprecedented."

Kathryn Harrington, a spokeswoman for

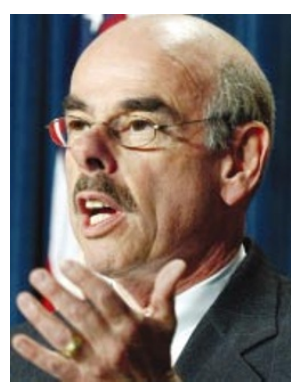

the White House Office of Science and Technology Policy, says that the report is unfair. "This administration does indeed look at the facts and reviews the best available science to make deciHenry Waxman: Bush's sions based on efforts to influence science what is best for the are 'unprecedented'. American people," Harrington says.

"We rely on people we elect not to use their power in ways that inappropriately distort knowledge," says Sheila Jasanoff, author of The Fifth Branch: Science Advisers as Policymakers (Harvard Univ. Press, Cambridge, Massachusetts, 1990) and a historian at Harvard University's Kennedy School of Government. "The strongest critique of the Bush administration is that this idea of delegation is being violated."

Critics say that the Bush administration's cavalier treatment of science has emboldened others to try to influence the scientific process. Last month, for example, Congress narrowly defeated a proposal by a Republican representative that would have blocked the NIH from funding five grants dealing with aspects of HIV, sexual health and behaviour, and wild animal populations. "The

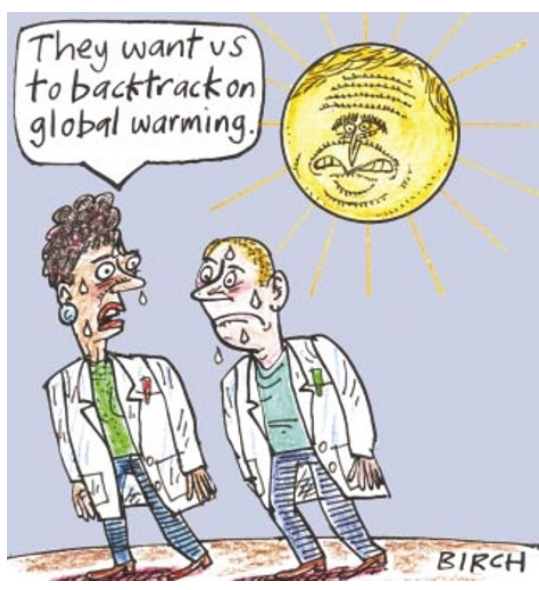

interference is now down to the grant level, and that should really be a cause of concern to the scientific community," says Gregg Gonsalves of New-York-based Gay Men's Health Crisis.

Scientists who have spoken out welcomed the report. They claim that the Bush administration's attempts to influence science put it in danger of becoming irrelevant on major issues related to science.

“After a while, people just won't believe the administration because, again and again, the policies are flying in the face of the facts," says Phil Coyle, assistant defence secretary until 2001, and now a consultant at the Washington-based Center for Defense Information. www.politicsandscience.org

\section{Biologists call for tracking as mammal numbers dive}

\section{Rex Dalton, Portland}

An agenda for marine-mammal research is being developed in the United States to try to save a range of often-elusive species from possible extinction.

More than 50 experts from around the world met in Portland, Oregon, on 4-7 August to consider priorities for research on dwindling populations of mammals such as whales, porpoises, sea lions, seals, otters, manatees and polar bears.

The US Marine Mammal Commission sponsored the meeting and will make recommendations later to Congress, which is considering changes to the Marine Mammal Protection Act. The US Navy and some commercial interests want to reduce protection, whereas marine biologists want to strengthen it.

Speakers at the Portland meeting backed development of a comprehensive monitoring and systematic sampling network to identify health issues and aid remedial plans. The creation of reservations in US waters -

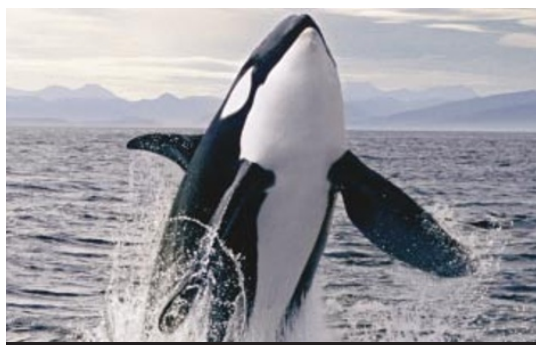

Deep trouble: marine mammals are hard to track and can be decimated before the alarm is raised.

where research could be done and regulatory regimes tried out - was also proposed.

"I am encouraged by the research ideas at the workshop," says John Hildebrand, who studies mammal acoustics at the Scripps Institution of Oceanography in La Jolla, California. "But I'm discouraged by the magnitude of the problems."

For more than 20 years, marine mammals have been protected by US federal law. But several species have been hit by factors such as loss of habitat, pollution, ocean noise and deaths inflicted by watercraft. The problems are worst for species, such as whales, that traverse unprotected international waters.

Jay Barlow, a marine biologist at the Southwest Fisheries Science Center in La Jolla, told the meeting it was so difficult to chart marine-mammal populations that $90 \%$ of a species could be lost before researchers realized it was in crisis.

Daniel Goodman, a zoological statistician at Montana State University in Bozeman, said that tracking needed new funding, not money from existing programmes.

There was little confidence that the Bush administration or the Republican-controlled Congress would provide the money. But scientists are optimistic that new research initiatives could be created.

On 19 August, a congressional subcommittee will hold a hearing in San Diego, where populations of seals and sea lions are so thriving that some residents and fishers are expected to call for a cull. 